\title{
AKFTA DAN PENINGKATAN LIBERALISASI AKSES PASAR JASA KOREA DAN INDONESIA PADA MODA COMMERCIAL PRESENCE
}

\author{
Herlitah, M.Ec.Dev \\ Fakultas Ekonomi Universitas Negeri Jakarta \\ herlitah@unj.ac.id
}

\begin{abstract}
This study aims to measure the degree of liberalization of the services sector in Korea and Indonesia Mode 3(CommercialPresence)in the WTO and cooperation as well as test singnifikansi AKFTA improvement. The method used to measure the level of liberalization is Hoekman index and the average difference test with t-test was used for testing out sigfikansi increased liberalization between the two countries of the WTO to AKFTA. The results showed that Korea has been more liberal than in Indonesia on the second of this cooperation. In cooperation WTO, Korea open as many as 104 sub-sectors with an average level of liberalization of 0.53 (scale 1), while Indonesia only open as many as 56 sub-sectors with an average index of 0.18. In cooperation AKFTA, Korea increase the number of sub-sectors to 147 with price liberalization level of 0.76. The number of sub-sectors of Indonesia also increased to 72 with an average level of liberalization of 0.22. Increasing the number of subsectors and the level of liberalization of Korea and Indonesia from the WTO to AKFTA based on the $t$-statistic is significant at the 5\% level. This means that both countries berliberalisasi significantly to liberalize the services sector.
\end{abstract}

Keywords: Trade in Services, Improved Rate Liberalization, WTO, AKFTA 


\section{PENDAHULUAN}

Perundingan perdagangan jasa pada fora multilateral di World Trade Organization (WTO) telah dimulai sejak putaran perundingan Uruguay pada tahun 1994 dan menghasilkan General Agreement on Trade in Services (GATS). Setiap negara meberikan liberalisasi untuk membuka sektor jasanya. Liberalisasi keterbukaan sektor jasa tersebut dituangkan dalam suatu jadwal yang di sebut dengan Schedule of Commitment (SOC). Keterbukaan sektor jasa yang dituangkan dalam SOC ini bersifat tidak diskriminasi atau berlaku untuk semua negara. Hal ini berdasarkan prinsip MostFavoured-Nation Treatment(MFN)yang tecantum dalam Article II GATS. MFN ini merupakan suatu kewajiban suatu anggota untuk memperlakukan penyedia jasa dari satu negara tidak lebih disukai daripada pemasok dari negara lain atau dengan kata lain semua penyedia jasa dari negaranegara anggota WTO diperlakukan sama.

Setelah lebih dari 20 tahun perberlakuan, WTO tidak menghasilkan kemajuan apapun (Deutsche Welle, 2014). Untuk itu, negara-negara angota WTO melakukan suatu perundingan diantaranya yaitu regional trade agreement (RTA). RTA adalah suatu mekanisme instutisional bagi pemerintah untuk komitmen liberalisasi perdagangan yang terpercaya (Hicks dan Kim, 2012). Perdagangan jasa merupakan salah satu topik penting yang dinegosiasikan dalam RTA ini. Pada RTA yang dilakukan oleh sesama negara maju, komponen sektor jasa yang dirundingkan sebesar 12 persen dan sektor barang sebesar 23 persen, kemudian olehsesama negaraberkembang sebesar 47 persen dan sektor barang 37 persen, sedangkan untuk sesama negara berkembang sebesar 41 persen untuk sektor jasa dan 40 persen untk sektor barang (Latrille dan Lee, 2012).

Salah satu kerjasama perdagangan yang diikuti dan telah ditandatangani oleh Indonesia adalah ASEAN-Korea Free http://doi.org/10.21009/econosains.015.2.1

Trade Agreement (AKFTA). Persetujuan bidang perdagangan jasa pada AKFTA ditandatangani pada saat KTT ASEAN di Singapura tahun 2007 dan persetujuan Investasi ASEAN Korea ditandatangani pada KTT ASEAN Korea pada bulan Juni 2009 di Jeju Island, Korea. Adapun pengesahan ditingkat domestik melalui Peraturan Presiden Republik Indonesia Nomor 11 Tahun 2007 tentangPengesahan Framework Agreement On Comprehensive economic Co-OperationAmong The Government of the Member Countries of the Association ofSoutheast Asian Nations and the Republic of Korea.

Kerjasama AKFTA ini merupakan satu-satunya RTA Indonesia dengan Korea. Untuk itu, diharapkan agar pada kerjasama ini, Indonesia akan mendapatkan liberalisasi liberalisasi perdagangan jasa yang lebih tinggi dari pada GATS. Hal ini disebabkan karena Indonesia telah mendapatkan akses pasar MFN dari Korea dalam GATS tersebut. Dalam kerjasama perdagangan AKFTA ini, Korea merupakan target utama Indonesia untuk mendapatkan akses pasar jasa karena akses pasar pasar jasa negaranegara ASEAN telah diperoleh melalui kerjasama ASEAN Framework Agreement on Services (AFAS). Berdasarkan hasil penelitian Ishido (2012), tingkat liberalisasi negara-negara ASEAN di AFAS rata-rata lebih tinggi daripada kerjasama ASEAN+1 yang salah satunya adalah AKFTA.

\section{Tinjauan Pustaka}

Antariksa $(2011)$ dalam
penelitiannya menjelaskan bahwa
liberalisasi perdagangan jasa adalah suatu
keadaan dimana setiap individu dan
perusahaan bebas untuk menjual jasa
melampaui batas-batas wilayah negaranya,
termasuk melalui fasilitas teknologi
informasi. Dalam kacamata teori
pembangunan liberal, konsep ini dianggap
dapat meningkatkan kesejahteraan


masyarakat internasional secara berkelanjutan.

Selain itu dalam penelitiannya Aldaba (2012) menjelaskan bahwa Perdagangan jasa merupakan komponen penting dalam strategi pembangunan negara. Untuk mengubah sektor ini menjadi sumber pertumbuhan utama membutuhkan upaya substansial untuk membuatnya lebih kompetitif dan efisien. Memperkenalkan persaingan melalui liberalisasi layanan di bawah AEC 2015 dapat menjadi katalis untuk mendorong daya saing sektor ini. Literatur empiris tentang keterkaitan antara liberalisasi jasa dan pertumbuhan ekonomi menunjukkan bahwa reformasi kebijakan yang meningkatkan persaingan dan memperbaiki pengawasan peraturan mengakibatkan peningkatan kinerja sektor yang bersangkutan.

Adapun kebijakan yang dapat dilakukan pemerintah dalam rangka liberalisasi yaitu dengan 2 (dua) cara, cara global atau unilateral serta dalam bentuk bilateral atau regional. Kebijakan bilateral atau regional adalah kebijakan yang dilakukan dengan kesepakatan secara regional ataupun multirateral yang terdapat dalam suatu perjanjian tertentu. Dalam bentuk global dilakukan sesuai dengan kesepakatan yang terdapat dalam WTO (World Trade Organization) yang merupakan induk dari perdagangan internasional. Sementara dalam bentuk unilateral menurut Sood (2012) dapat dilakukan secara sepihak oleh suatu negara.

Selain itu Aldaba menjelaskan secara umum, hambatan dalam perdagangan jasa diklasifikasikan dalam hal apakah mereka membatasi akses pasar pada umumnya (contohnya; kebijakan yang membatasi jumlah penyedia layanan) atau secara khusus mempengaruhi pemasok jasa asing dengan menolak perlakuan nasional (contohnya; sebuah kebijakan yang membatasi Kepemilikan saham). Pembatasan peraturan dapat mengurangi persaingan dan efisiensi di sektor jasa. Hambatan masuk mengurangi persaingan dan memungkinkan perusahaan incumbent untuk mendominasi pasar.

\section{METODE}

\section{Metode Analisis}

Metode yang digunakan dalam penelitian ini terdiri dari metode indeksasi dengan indeks hoekman, metode deskriptif statistik dan metode uji beda rata-rata. Adapun penjelasan masing-masing metode tersebut adalah sebagai berikut.

- Indeks hoekman

Indeksasi dengan indeks hoekman ini digunakan untuk mengukur tingkat liberalisasi yang usulkan oleh Hoekman (1995). Oleh karena dukumen tingkat liberalisasi sektor jasa bersifat kualitatif maka dengan indeksasi ini akan diperoleh suatu skala kuantitatif sehinnga akan lebih mudah untuk memperbandingkan tingkat liberalisasi.

Tabel 1. Kriteria Tingkat Liberalisasi Berdasarkan Besarnya Nilai Indeks

hoekman

\begin{tabular}{|c|c|c|}
\hline No & Indeks Hoekman & Keterangan Tingkat Liberalisasi \\
\hline 1 & $0,76-1$ & Tinggi \\
\hline 2 & $0,5-0,75$ & Sedang \\
\hline 3 & $0,25-0,49$ & Rendah \\
\hline
\end{tabular}

Sumber: Fawaiq (2014), disesuaikan

- Deskriptif Statistik

Dari hasil indeksasi dengan indeks hoekman kemudian 
dilakukan rata-rata mean. Nilai rata-rata ini akan dideskripsikan pada setiap sektor jasa (12 sektor) untuk diperbandingkan sektor tingkat liberalisasi pada setiep subsektor pada masing-masing negara. Dari nilai rata-rata ini akan diketahui sektor jasa tertentu yang paling tinggi tingkat liberalisasi akses pasarnya.

- Uji beda rata-rata dengan uji t

Analisis uji beda digunakan untuk mengetahui apakah Korea memberikan liberalisasi pada AKFTA yang berbeda dengan liberalisasinya pada WTO. Setelah melakukan indeksasi dengan indeks hoekman pada SOC Korea di WTO dan di AKFTA kemudian dikembangkan hipotesi sebagai berikut.

$\mathrm{H}_{0}$ :tidak terdapat perbedaan yang signifikan antara liberalisasi Korea di WTO dengan di AKFTA;

$\mathrm{H}_{1}$ : terdapat perbedaan yang signifikan antara liberalisasi Korea di WTO dengan di AKFTA.

Dari hipotesis tersebut dapat disusun teknis pengolahan data secara manual berdasarkan tabel berikut berikut:

\section{Tabel 2. Perhitungan uji t-statistik secara manual}

\begin{tabular}{|c|c|c|}
\hline $\begin{array}{c}\text { Liberalisasi Korea di WTO } \\
\text { X1 }\end{array}$ & $\begin{array}{c}\text { Liberalisasi Korea di AKFTA } \\
\text { X2 }\end{array}$ & $\begin{array}{c}\text { Selisih (D) } \\
\mathrm{D}=\mathrm{X} 1-\mathrm{X} 2\end{array}$ \\
\hline
\end{tabular}

Setelah itu, kemudian dihitung nilai standar deviasinya (S) dengan jumlah sampel (n) dan selisih (D) dengan formula sebagai berikut:

$S=\sqrt{\frac{1}{n-1}}\left\{\sum D-\frac{\left(\sum D\right)^{2}}{n}\right\}$

Kemudian dihitung nilai t hitungnya dengan formula sebagai berikut.

$t=\frac{\sum D}{\frac{n}{\frac{5}{\sqrt{n}}}}$

Setelah diperoleh nilai t-hitung atau t-statistik kemudian diperbandingkan dengan nilai $\mathrm{t}$ table pada taraf 5 persen. Setelah itu, dilakukan pengujian hipotesi yaitu menolak $\mathrm{H}_{0}$ apabila nilai $\mathrm{t}-$ statistik berada dalam wilaya kritis dan menerima $\mathrm{H}_{0}$ apabila nilai $\mathrm{t}$ statistik berada di luar wilayah kritis. Dalam penelitian ini, pengolahan data untuk uji beda rata-rata akan dilakukan secara otomatis menggunakan program microsoft excel. Prosedur pengolahan data tersbut dimulai menginput data ke microsoft excel, kemudian memilih menu Data kemudian menu Data Analysis, kemudian memilih menu paired two sample for means.

\section{Data}

Data utama yang digunakan dalam penelitian ini adalah data dokumen liberalisasi jasa AKFTA yang disebut dengan Schedule of Commitment (SOC). Dokumen SOC ini memuat tingkat liberalisasi 12 sektor jasa secara kualitatif pada 4 (empat) moda suplai jasa dan 2 (dua) kolom pembatasan. Ke dua belas sektor jasa tersebut berdasarkan Dokumen WTO No. W/120 (1991) adalah jasa 
bisnis, jasa komunikasi, jasa konstruksi dan jasa teknik terkait, jasa distribusi, jasa pendidikan, jasa lingkungan, jasa keuangan, jasa terkait kesehatan dan sosial, jasa pariwisata dan perjalanan, jasa rekreasi, budaya, dan olahraga, jasa perhubungan, jasa lainnya. Adapun moda suplai jasa berdasarkan GATS dan Undang-undang Nomor 7 Tahun 2014 Tentang Perdagangan yaitu pasokan lintas batas/Moda 1, konsumsi di luar negeri(Moda 2), keberadaan komersial(Moda 3), dan perpindahan manusia(Moda 4). Pada penelitian ini hanya akan difoukuskan pada Moda 3. Hal ini disebabkan karena Moda1 dan Moda 2 sebagian besar sudah diliberalisasi oleh Korea dan Indonesia, sementara Moda 4 masih cenderung tertutup.

Pembatasan-pembatasan setiap sektor jasa dan moda suplai jasa dituliskan dalam 2 (dua) kolom SOC yaitu kolom pembatasan akses pasar dan kolom pembatasan perlakuan nasional. Adapun hal-hal yang dimuat dalam kolom pembatasan akses pasar sesuai dengan Para 39 GATS adalah Pembatasan pada jumlah penyedia jasa;pembatasan pada total nilai transaksi atau aset;pembatasan pada jumlah jasa yang beroperasi dan kuantitas dari output;pembatasan pada jumlah total natural person;pembatasan jenis dari entitas legal atau joint ventura;dan pembatasan pada partisipasi modal asing(WTO, 2001 dalam Fawaiq, 2014). Lebih lanjut untuk pembatasan pada kolom perlakuan nasional adalah deskriminasi pada subsidi dan tindakantindakan keuangan lainnya;kewarganegaraan yaitu warga negara atau permanen residen;persyaratan mengenai perijinan, kualifikasi dan registrasi;persyaratan alih teknologi dan pelatihan;persyaratan muatan lokal;larangan kepemilikan lahan atau properti; dan pembatasan pada jaminan portabilitas dan penggunaan dana pendidikan.Kedua kolom pada SOC ini dikuantifikasi tingkat keterbukaannya dengan Indeks Hoekman pada Moda 3 di masing-masing subsektor kemudian diratarata.

\section{HASIL DAN PEMBAHASAN}

\section{Perbandingan Tingkat Liberalisasi Jasa Korea dan Indonesia di Tingkat WTO dan AKFTA}

Pada kerjasama WTO sektor jasa di Moda 3, Korea membuka sebanyak 104 subsektor sedangkan Indonesia membuka dengan jumlah yang lebih sedikit yaitu sebanyak 56 subsektor. Jumlah subsektor yang dibuka oleh Korea meningkat sebanyak 43 subsektor menjadi 147 subsektor pada kerjasama AKFTA. Adapun Indonesia hanya menambah 16 subsektor menjadi 72 subsektor pada kerjasama AKFTA. Subsektor-subsektor jasa di Moda 3 yang dibuka oleh Korea dan Indonesia dan tingkat liberalisasinya adalah sebagai berikut.

\section{Sektor Jasa Bisnis}

Jumlah subsektor di sektor jasa bisnis yang dibuka oleh Korea pada kerjasama WTO adalah sebanyak 34 subsektor, dimana 30 diantaranya diberikan tingkat liberalisasi penuh dengan indeks hoekman 1 . Siasanya sebanyak 4 (empat) subsektor dibuka dengan pembatasan dengan Indeks Hoekman 0,5 atau dengan tingkat liberalisasi sedang. Subsektorsubsektor jasa bisnis yang dibuka oleh Korea dengan tingkat liberalisasi penuh atau tanpa pembatasan pada kerjasama WTO antara lain jasa arsitektur, jasa rekayasa,semua subsektor pada kategori jasa computer, dan sebagainya. Adapun Indonesia membuka sebanyak 10 subsektor dengan indeks hoekman 0,5 atau terbuka dengan pembatasan. Banyaknya jumlah subsektor yang dibuka serta diberikan tingkat liberalisasi penuh oleh Korea pada tingkat WTO menunjukkan bahwa 
Korea telah jauh lebih liberal daripada Indonesia. Selain itu, Indonesia telah memperoleh akses pasar yang besar dari Korea di kerjasama WTO.

Pada kerjasama AKFTA yang melibatkan Indonesia, Korea menambah jumlah subsektor pada sektor jasa bisnis menjadi 50 subsektor. Tingkat liberalisasi yang diberikan oleh AKFTA adalah 43 subsektor diberikan tingkat liberalisasi penuh $(\mathrm{IH}=1)$, dan 7 subsektor dibuka dengan pembatasan. Pada kerjasama ini, Indonesia cenderung lebih tertutup karena hanya membuka sebanyak 12 subsektor dengan Indeks Hoekman yang sama dengan yang berikan pada WTO. Hal ini menunjukkan tingginya liberalisasi Korea untuk lebih meliberalisasi sektor jasa bisnisnya dari yang sebelumnya di WTO. Adapun tingkat liberalisasi sektor jasa Korea dan Indonesia pada kerjasama WTO dan AKFTA disajikan pada Tabel 3 .

\section{Tabel 3. TingkatLiberalisasiKorea dan Indonesia Pada Kerjasama WTO dan} AKFTA di Sektor Jasa Bisnis.

\begin{tabular}{|c|c|c|c|c|}
\hline \multirow[t]{2}{*}{ Sub sektor } & \multicolumn{2}{|c|}{ Korea } & \multicolumn{2}{|c|}{ Indonesia } \\
\hline & WTO & AKFTA & WTO & AKFTA \\
\hline \multicolumn{5}{|l|}{ - Jasa Profesional } \\
\hline 1. Jasa hukum; (CPC 861*). & 0 & 0,5 & 0 & 0 \\
\hline 2. Jasa akuntansi, audit dan pembukuan (CPC 862). & 0,75 & 0,75 & 0 & 0 \\
\hline 3. Jasa perpajakan (CPC 863). & 0,75 & 0,75 & 0 & 0 \\
\hline 4. Jasa manajemen proyek selain untuk konstruksi (CPC 86601). & 0 & 0 & 0 & 0,5 \\
\hline 5. Jasa arsitektur (CPC 8671). & 1 & 1 & 0,5 & 0,5 \\
\hline $\begin{array}{l}\text { 6. Jasa rekayasa (CPC 8672) (Indonesia WTO: CPC 86721, } 86725 \text { kecuali } \\
\text { CPC 86721, 86725, 86726), (Indonesia AKFTA: termasuk 86721, } \\
\text { 86725). }\end{array}$ & 1 & 1 & 0,5 & 0,5 \\
\hline 7. Integrated engineering services (CPC 8673). & 1 & 1 & 0,5 & 0,5 \\
\hline $\begin{array}{l}\text { 8. Jasaperencanaan kota dan arsitektur pemandangan (CPC 8674) } \\
\text { (Indonesia: CPC 86742). }\end{array}$ & 1 & 1 & 0,5 & 0,5 \\
\hline 9. Jasa kedokteran hewan (CPC 932). & 0 & 1 & 0 & 0 \\
\hline \multicolumn{5}{|l|}{ - Komputer dan Jasa Terkait } \\
\hline $\begin{array}{l}\text { 10. Jasa konsultasi yang berkaitan dengan instalasi perangkat keras } \\
\text { komputer (CPC } 841 \text { ) }\end{array}$ & 1 & 1 & 0,5 & 0,5 \\
\hline 11. Jasa implementasi perangkat lunak (CPC 842) & 1 & 1 & 0,5 & 0,5 \\
\hline 12. Jasa pengolahan data (CPC 843 ) & 1 & 1 & 0 & 0 \\
\hline 13. Jasa basis data (CPC 844) & 1 & 1 & 0 & 0,5 \\
\hline 14. Lainnya (CPC 845,849$)$ & 1 & 1 & 0 & 0 \\
\hline \multicolumn{5}{|l|}{ Jasa Penelitian dan Pengembangan } \\
\hline 15. Penelitian dan pengembangan di ilmu sosial dan humaniora (CPC 852) & 1 & 1 & 0 & 0 \\
\hline 16. Jasa penelitian dan pengembangan interdisipliner (CPC 853) (Indonesia & 0 & 0 & 0,5 & 0,5 \\
\hline
\end{tabular}

(WTO): terbatas pada kegiatan industri)

\begin{tabular}{|c|c|c|c|c|}
\hline • Jasa Perumahan & & & & \\
\hline 17. Jasa perantara (CPC $\left.82203^{*}, 82204^{*}, 82205^{*}, 82206^{*}\right)$ & 0 & 1 & 0 & 0 \\
\hline 18. Jasa penilai (CPC $82201^{*}, 82202^{*}$ ) & 0 & 1 & 0 & 0 \\
\hline \multicolumn{5}{|l|}{ - Jasa Penyewaan / Kontrak Sewa Tanpa Operator } \\
\hline 19. Berkaitan dengan kapal (CPC 83103). & 1 & 1 & 0 & 0 \\
\hline 20. Berkaitan dengan pesawat (CPC 83104) & 0,5 & 0,5 & 0 & 0 \\
\hline 21. Berkaitan dengan peralatanangkutan lainnya (CPC 83101, 83105). & 1 & 1 & 0 & 0 \\
\hline 22. Berkaitan dengan mesin dan peralatan lainnya (CPC 83106-83109). & 1 & 1 & 0 & 0 \\
\hline $\begin{array}{l}\text { 23. Jasa penyewaan lainnya terkait dengan barang pribadi atau rumah } \\
\text { tangga (CPC 832). }\end{array}$ & 0 & 1 & 0 & 0 \\
\hline
\end{tabular}

- Jasa Bisnis Lainnya 


\begin{tabular}{|c|c|c|c|c|}
\hline \multirow[t]{2}{*}{ Sub sektor } & \multicolumn{2}{|c|}{ Korea } & \multicolumn{2}{|c|}{ Indonesia } \\
\hline & WTO & AKFTA & WTO & AKFTA \\
\hline 24. Jasa periklanan (CPC 871). & 1 & 1 & 0 & 0 \\
\hline $\begin{array}{l}\text { 25. Jasa riset pasar dan publik. } \\
\text { 26. Jajak pendapat (CPC 864). }\end{array}$ & 1 & 1 & 0 & 0 \\
\hline 27. Jasa konsultasi manajemen (CPC 865). & 1 & 1 & 0 & 0 \\
\hline 28. Jasa manajemen proyek dan jasa manajemen lainnya (CPC 86601). & 1 & 1 & 0 & 0 \\
\hline 29. Jasa manajemen proyek dan jasa manajemen lainnya (CPC 86609). & 0 & 1 & 0 & 0 \\
\hline $\begin{array}{l}\text { 30. Jasa komposisi dan pengujian kemurnian serta jasa analisis (CPC } \\
86761 \text { ). }\end{array}$ & 0,75 & 0,75 & 0 & 0 \\
\hline $\begin{array}{l}\text { 31. Jasa Pengujian dan analisis sifat fisik (CPC 86.762) (Indonesia CPC } \\
\text { 8676). }\end{array}$ & 0 & 1 & 0,5 & 0,5 \\
\hline 32. Jasa pemeriksaan teknis (CPC 86764). & 1 & 1 & 0 & 0 \\
\hline $\begin{array}{l}\text { 33. Jasa pengujian, analisis sistem mekanik dan listrik terintegrasi } \\
\text { (CPC } 86763 * *, 86769^{* *} \text {. }\end{array}$ & 0 & 0,5 & 0 & 0 \\
\hline $\begin{array}{l}\text { 34. Jasa konsultasi terkaitdengan pertanian dan hewanpertanian (CPC } \\
\left.8811^{*}, 8812^{*}\right)\end{array}$ & 1 & 1 & 0 & 0 \\
\hline 35. Jasa diferensiasi unggas (CPC $\left.8811^{* *}, 8812 * *\right)$ & 0 & 1 & 0 & 0 \\
\hline $\begin{array}{l}\text { 36. Jasa yang terkait dengan kehutanan termasuk pemadaman kebakaran } \\
\left.\text { udaradan desinfeksi (CPC } 8814^{*}\right) \text {. }\end{array}$ & 1 & 1 & 0 & 0 \\
\hline 37. Jasa konsultasi yang berkaitan dengan fishing $(\mathrm{CPC} 882 *)$ & 1 & 1 & 0 & 0 \\
\hline 38. Jasa incidental untuk pertambangan (CPC 883) & 1 & 1 & 0 & 0 \\
\hline $\begin{array}{l}\text { 39. Jasa yang terkait dengan manufaktur: hanya jasa yang berkaitan dengan } \\
\text { konsultasi teknologi manufaktur untuk produk baru (CPC } 884 * \text { dan } \\
885 * \text { termasuk } 88.411,88.450,88.442 \text {, dan } 88.493)\end{array}$ & 0 & 1 & 0,5 & 0,5 \\
\hline 40. Jasa penempatan tenaga (CPC 87201, 87202). & 0 & 0,75 & 0 & 0 \\
\hline $\begin{array}{l}\text { 41. Jasa terkait ilmiah dan konsultasi teknis, jasa propek keilmuan geologi, } \\
\text { geofisika dan lainnya (CPC 86.751) serta jasa survei bawah permukaan } \\
\text { (CPC 86.752). }\end{array}$ & 1 & 1 & 0 & 0 \\
\hline 42. Jasa survei permukaan (CPC 86753*). & 0 & 1 & 0 & 0 \\
\hline 43. Jasa pembuatan peta (CPC $86754 *)$ & 0 & 1 & 0 & 0 \\
\hline $\begin{array}{l}\text { 44. Pemeliharaan dan perbaikan peralatan (CPC } 633,8861,8862,8863 \text {, } \\
8864,8865,8866) \text {. }\end{array}$ & 1 & 1 & 0,5 & 0,5 \\
\hline 45. Jasa pembersihan gedung (CPC $874 * *$, tidak termasuk 87409 ). & 0 & 1 & 0 & 0 \\
\hline 46. Jasa fotografi (CPC 875) & 1 & 1 & 0 & 0 \\
\hline 47. Jasa pengemasan (CPC 876). & 1 & 1 & 0 & 0 \\
\hline 48. Jasa percetakan (CPC 88442*). & 1 & 1 & 0 & 0 \\
\hline 49. Jasa penerbitan (CPC $88442 *$ ). & 0 & 1 & 0 & 0 \\
\hline 50. Jasa lembaga konvensi (CPC $87909 \%)$. & 1 & 1 & 0 & 0 \\
\hline 51. Jasa stenografi (CPC 87909*). & 1 & 1 & 0 & 0 \\
\hline 52. Jasa terjemahan dan interpretasi (CPC 87905). & 1 & 1 & 0 & 0 \\
\hline 53. Jasa desain khusus (CPC 87907). & 0 & 1 & 0 & 0 \\
\hline
\end{tabular}

Sumber: data diolah

Berdasarkan Tabel 3, pada kerjasama WTO, Korea masih menutup jasa perumahan dan membukanya pada kerjasama AKFTA dengan liberalisasi secara penuh tanpa pembatasan. Hal ini juga dilakukan Korea pada beberapa subsektor lainnya seperti subsektor jasa manajemen proyek, jasa pembersihan gedung, jasa penerbitan dan sebagainya. Perubahan tingkat liberalisasi Korea pada beberapa subsektor yang baru dibuka pada kerjasama AKFTA tersebut yaitu dari tertutup $(\mathrm{IH}=0)$ menjadi terbuka penuh tanpa pembatasan (IH = 1). Adapun Indonesia memberikan tingkat liberalisasi yang relatif sama pada kedua kerjasama ini. Subsektor jasa bisnis Indonesia yang mengalami peningkatan tingkat liberalisasi adalah jasa professional dan jasa Komputer. Khusus untuk jasa hukum yang masih ditutup oleh Indonesia,pihak Korea menginginkan agar Indonesia 
membuka sektor jasa ini (Tongson dan Cheong, 2016). Lebih lanjut dijelaskan bahwa jasa konsultan hukum dibutuhkan pada saat pendirian perusahaan Korea di Indonesia.

\section{Sektor Jasa Komunikasi}

Pada sektor jasa komunikasi, Korea meliberalisasi sebanyak 18 subsektor di kerjasama WTO dan ditambah dua subsektor menjadi 20 subsektor pada kerjasama AKFTA. Indonesia meliberalisasi sektor jasa komunikasinya dengan jumlah yang lebih sedikit yaitu sebanyak 14 subsektor di WTO dan pada kerjasama AKFTA tidak adah penambahan jumlah subsektor. Adapun tingkat liberalisasi rata-rata pada setiap kategori jasa komunikasi disajikan pada Tabel 4 sebagai berikut.

Tabel 4. Tingkat LiberalisasiKorea dan IndonesiaPada Kerjasama WTO dan AKFTA di Sektor Jasa Komunikasi.

\begin{tabular}{|c|c|c|c|c|}
\hline \multirow[t]{2}{*}{ Sub sektor } & \multicolumn{2}{|c|}{ Korea } & \multicolumn{2}{|c|}{ Indonesia } \\
\hline & WTO & AKFTA & WTO & AKFTA \\
\hline \multicolumn{5}{|l|}{ - Jasa Kurir } \\
\hline 1. Jasa kurir internasional (CPC $75121^{* *}$ ). & 0 & 0,5 & 0 & 0 \\
\hline \multicolumn{5}{|l|}{ • Jasa telekomunikasi } \\
\hline 2. Jasa telepon suara. & 0,75 & 0,75 & 0,75 & 0,75 \\
\hline 3. Jasa transmisi data packet-switched. & 0,75 & 0,75 & 0,75 & 0,75 \\
\hline 4. Jasa transmisi data circuit-switched. & 0,75 & 0,75 & 0,75 & 0,75 \\
\hline 5. Jasa teleks. & 0,75 & 0,75 & 0,75 & 0,75 \\
\hline 6. Jasa telegraf. & 0,75 & 0,75 & 0,5 & 0,75 \\
\hline 7. Jasa faksimili. & 0,75 & 0,75 & 0,75 & 0,5 \\
\hline 8. Jasa leased circuit pribadi. & 0,75 & 0,75 & 0 & 0 \\
\hline \multicolumn{5}{|l|}{ Jasa telekomunikasi lainnya. } \\
\hline $\begin{array}{l}\text { 9. Jasa seluler digital, layanan paging PCS (personal communications } \\
\text { services); TRS (trunked radio system); Mobile data; IAS (Internet access- } \\
\text { services); and VoIP (Voice over Internet protocol), jasa yang terhubung } \\
\text { pada PSTN (public switched telephone network). }\end{array}$ & 0,75 & 0,75 & 0,75 & 0,75 \\
\hline \multicolumn{5}{|l|}{ - Jasa nilai tambah } \\
\hline 10. Electronic mail. & 1 & 1 & 0,5 & 0,5 \\
\hline 11. Electronic mail box. & 0,5 & 0,5 & 0,5 & 0,75 \\
\hline 12. Surat suara. & 1 & 1 & 0,5 & 0,5 \\
\hline 13. Informasi online dan pengambilan database. & 1 & 1 & 0 & 0 \\
\hline 14. Pertukaran data elektronik. & 1 & 1 & 0 & 0 \\
\hline $\begin{array}{l}\text { 15. Ditingkatkan / nilai tambah jasa faksimili termasuk store dan forward, store } \\
\text { dan retrief. }\end{array}$ & 1 & 1 & 0 & 0 \\
\hline 16. Kode dan protokol konversi. & 1 & 1 & 0 & 0 \\
\hline $\begin{array}{l}\text { 17. Information on-line dan/atau pengolahan data (termasuk pengolahan } \\
\text { transaksi). }\end{array}$ & 1 & 1 & 0 & 0 \\
\hline
\end{tabular}

\begin{tabular}{l} 
- Jasa nilai tambah lainnya \\
\hline 18. Database online dan layanan komputasi jarak jauh
\end{tabular}

- Jasa Audiovisual
22. Jasa gambar bergerak dan produksi video tape dan distribusinya

Sumber: data diolah 
Dari 18 subsektor jasa yang dibuka Korea di WTO, 9 diantaranya diliberalisasi secara penuh atau tanpa pembatasan $(\mathrm{IH}=1)$. Subsektor jasa tersebut antara lain jasa surat elektronik, jasa pertukaran data elektronik, jasa gambar bergerak, produksi video tape dan distribusinya, dan sebagainya (lihat lampiran 2). Adapun peningkatan liberaliasi Korea dari WTO ke AKFTA sebagaimana ditunjukkan pada Tabel 4, terjadi pada kategori jasa kurir dan pjasa nilai tambah telekomunikasi lainnya.

\section{Sektor Jasa Konstruksi}

Korea dan Indonesia meliberalisasi sektor jasa konstruksi pada kerjasama WTO dengan jumlah subsektor yang sama yaitu masing-

Tabel 5. Tingkat LiberalisasiKorea dan IndonesiaPada Kerjasama WTO dan AKFTA di Sektor Jasa Konstruksi

\begin{tabular}{|c|c|c|c|c|}
\hline \multirow[t]{2}{*}{ Sub-sektor } & \multicolumn{2}{|c|}{ Korea } & \multicolumn{2}{|c|}{ Indonesia } \\
\hline & WTO & AKFTA & WTO & AKFTA \\
\hline $\begin{array}{l}\text { 1. Persiapan-pemancangan pekerjaan konstruksi (CPC 511, Indonesia } \\
\text { WTO: kecuali CPC } 51110 \text { and 51113). }\end{array}$ & 1,0 & 1,0 & 0,5 & 0,5 \\
\hline $\begin{array}{l}\text { 2. Pekerjaan konstruksi untuk bangunan (CPC 512, Indonesia: except } \\
\text { CPC 51210). }\end{array}$ & 0,0 & 1,0 & 0,5 & 0,5 \\
\hline 4. Perakitan dan pemancangan prafabrik konstruksi (CPC 514). & 0,75 & 1,0 & 0,5 & 0,5 \\
\hline 5. Perdagangan khusus jasa konstruksi (CPC 515). & 0,75 & 1,0 & 0,5 & 0,5 \\
\hline 6. Pekerjaan instalasi (CPC 516). & 0,75 & 1,0 & 0,0 & 0,0 \\
\hline 7. Penyelesaian Bangunan dan Pekerjaan Penyelesaian Akhir (CPC517). & 0,75 & 1,0 & 0,0 & 0,5 \\
\hline 8. Jasa penyewaan (CPC 518). & 0,00 & 1,0 & 0,5 & 0,5 \\
\hline
\end{tabular}

Sumber: data diolah

Walaupun pada kerjasama

WTO Korea telah meliberalisasi jasa konstruksinya dengan dengan tingkat liberalisasi sedang dengan indeks hoekman 0,75 yang lebih tinggi dari Indonesia ( $\mathrm{IH}=0,5)$, namun Korea terus meningkatkan liberalisasinya menjadi terbuka penuh dengan kategori liberalisasi tinggi $(\mathrm{IH}=1)$. Untuk Indonesia, rata-rata tingkat liberalisasi jasa konstruksinya adalah terbuka tanpa pembatasan baik di WTO maupun di AKFTA. Namun demikian, masing sebanyak enam subsektor. Namun demikian, terdapat perbedaan antara Korea dan Indonesia yaitu pada jenis subsektornya. Indonesia belum meliberalisasi subsektor jasa pekerjaan instalasi dan jasa penyelesaian bangunan dan pekerjaan penyelesaian akhir, sementara Korea belum meliberalisasi jasa pekerjaan konstruksi untuk bangunan dan jasa penyewaan. Pada kerjasama AKFTA kedua negara masing-masing meningkatkan sebanyak dua subsektor. Adapun subsektorsubsektor jasa konstruksi yang dibuka serta tingkat liberalisasinya disajikan pada Tabel 5. 
signifikan menjadi 73 pada tahun 2012.

\section{Sektor Jasa Distribusi}

Indonesia belum meliberalisasi jasa distribusinya baik pada kerjasama WTO maupun AKFTA, sementara Korea membuka tiga subsektor dengan tingkat liberalisasi sedang $(\mathrm{IH}=0,75)$ dan satu subsektor dengan kategori liberalisasi tinggi ( $\mathrm{IH}=1)$. Peningkatanliberalisasi Korea dari WTO ke AKFTA hanya pada jasa waralaba yang meningkat dari tingkat liberalisasi sedang $(\mathrm{IH}=$ 0,75) menjadi tingkat liberalisasi tinggi $(\mathrm{IH}=1)$. Keterbukaan jasa distribusi Korea di AKFTA ini merupakan peluang bagi Indonesia untuk mengekspor jasanyamelalui Moda 3 (commercial presence). Sebelumnya, Indonesia telah berhasil mengeskor jasa ritelnya ke Filipina, walaupun negara tersebut masih menutup sektor jasa distribusinya (Fawaiq, 2015). Tingginya tingkat liberalisasi jasa distribusi Korea ini menunjukkan besarnya peluang akses pasar bagi Indonesia dalam pemanfaatan di masa depan. Adapun tingkat liberalisasi pada setiap subsektor jasa distribusi disajikan pada Tabel 6 sebagai berikut.

Tabel 6. Tingkat LiberalisasiKorea dan IndonesiaPada Kerjasama WTO dan AKFTA di Sektor Jasa Distribusi

\begin{tabular}{|c|c|c|c|c|}
\hline \multirow[t]{2}{*}{ Sub-sektor } & \multicolumn{2}{|c|}{ Korea } & \multicolumn{2}{|c|}{ Indonesia } \\
\hline & WTO & AKFTA & WTO & AKFTA \\
\hline $\begin{array}{l}\text { 1. Agen komisi (CPC 621, tidak termasuk } \\
62111,62112 \text { ). }\end{array}$ & 1,00 & 1,00 & 0,00 & 0,00 \\
\hline $\begin{array}{l}\text { 2. Jasa grosir (CPC 622, tidak termasuk biji-bijian di } \\
\text { 62211, 62223, ginseng, ginseng merah dan produk } \\
\text { seperti tepung di } 62229 \text { dan pupuk di 62276). }\end{array}$ & 0,75 & 0,75 & 0,00 & 0,00 \\
\hline $\begin{array}{l}\text { 3. Jasa ritel (CPC 6111, 61130, 61210, 613* (tidak } \\
\text { termasuk perdagangan dan SPBU bisnis ritel yang } \\
\text { berhubungan dengan LPG), } 631 * \text { (tidak termasuk } \\
\text { tembakau, beras, ginseng dan ginseng merah), } 632 \text {. }\end{array}$ & 0,75 & 0,75 & 0,00 & 0,00 \\
\hline
\end{tabular}

4. Waralaba (CPC 8929*).

0,75

1,00

0,00

0,00

Sumber: data diolah

\section{Jasa Pendidikan}

Korea dan Indonesia hanya membuka sektor jasa pendidikan pada kerjasama AKFTA. Jumlah subsektor yang dibuka adalah dua subsektor untuk Korea dan tiga subsektor untuk Indonesia. Tingkat liberalisasi yang diberikan oleh kedua negara adalah rendah. Pada

Tabel 7. Tingkat LiberalisasiKorea dan IndonesiaPada Kerjasama WTO dan AKFTA di Sektor Jasa Pendidikan

\begin{tabular}{|c|c|c|c|c|}
\hline \multirow[t]{2}{*}{ Sub-sektor } & \multicolumn{2}{|c|}{ Korea } & \multicolumn{2}{|c|}{ Indonesia } \\
\hline & WTO & AKFTA & WTO & AKFTA \\
\hline 1. Jasa pendidikan tinggi (CPC $\left.923^{* *}\right)$. & 0 & 0,25 & 0 & 0,25 \\
\hline 2. Jasa pendidikan orang dewasa (CPC $924 * *$ ). & 0 & 0,25 & 0 & 0,25 \\
\hline 3. Jasa pendidikan lainnya (Indonesia: sepak bola dan catur). & 0 & 0 & 0 & 0,25 \\
\hline
\end{tabular}

sektor jasa pendidikan ini Indonesia membuka sektor jasa pendidikan sepak bola dan sekolah catur sementara Korea tidak menambahkan subsektor tersebut. Tingkat liberalisasi setiap subsektor di jasa pendidikan disajikan pada Tabel 7 sebagai berikut.

Sumber: data diolah 
Tabel 7 menunjukkan bahwa kedua negara telah membuka seksektor jasa pendidikan tingginya, walaupun dengan tingkat liberalisasi yang termasuk rendah. Hal ini akan menjadi awal liberalisasi pendidikan tinggi khususnya di Moda 3. Iyiomo dan Sanjo (2012) melakukan penelitian mengenai dampak GATS pada pendidikan di Nigeria dan menemukan bahwa GATS berpengaruh pada aktifitas bisnis dan pendidikan. Lebih lanjut dijelaskan bahwa kualitas pendidikan meningkat dengan masuknya penyedia jasa pendidikan asing serta meningkatnya kapasitas nasional.

\section{Sektor Jasa Lingkungan}

Indonesia belum meliberalisasi sektor jasa lingkunganya pada kerjasama WTO dan AKFTA. Adapun Korea meliberalisasi sebanyak empat subsektor pada kerjasama WTO dan ditingkatkan menjadi enam subsektor di AKFTA. Tingkat liberalisasi Korea di WTO termasuk sedang pada tiga subsektor $(\mathrm{IH}=0,75)$ dan tinggi pada satu subsektor $(\mathrm{IH}=1)$. Tingkat liberalisasi pada masing-masing subsektor di sektor jasa lingkungan di sajikan pada Tabel 8.

Tabel 8. Tingkat LiberalisasiKorea dan IndonesiaPada Kerjasama WTO dan AKFTA di Sektor Jasa Lingkungan.

\begin{tabular}{|c|c|c|c|c|}
\hline \multirow[t]{2}{*}{ Sub-sektor } & \multicolumn{2}{|c|}{ Korea } & \multicolumn{2}{|c|}{ Indonesia } \\
\hline & WTO & AKFTA & WTO & AKFTA \\
\hline \multicolumn{5}{|l|}{ Jasa limbah } \\
\hline 1. Jasa limbah pembuangan air (CPC 9401*). & 0,75 & 1,00 & 0,00 & 0,00 \\
\hline \multicolumn{5}{|l|}{ - Jasa pembuangan } \\
\hline 2. Jasa pembuangan sampah industri (CPC $9402 \%)$. & 0,75 & 1,00 & 0,00 & 0,00 \\
\hline \multicolumn{5}{|l|}{ - Jasa lingkungan lainnya } \\
\hline $\begin{array}{l}\text { 3. Jasa pembersihan gas buang dan jasa pengurangan kebisingan } \\
\text { (CPC 9404, 9405). }\end{array}$ & 1,00 & 1,00 & 0,00 & 0,00 \\
\hline 4. Jasa pengujian danpenilaian lingkungan(CPC 9406*, 9409*). & 0,75 & 1,00 & 0,00 & 0,00 \\
\hline 5. Jasa perbaikan dan pemurnian tanah (CPC 9404*). & 0,00 & 1,00 & 0,00 & 0,00 \\
\hline 6. Jasa konsultan lingkungan (CPC $9409^{*}$ ). & 0,00 & 1,00 & 0,00 & 0,00 \\
\hline
\end{tabular}

Sumber: data diolah

\section{Sektor Jasa Keuangan}

Jumlah subsektor jasa keuangan yang dibuka oleh Korea pada kerjasama WTO sebanyak 22 subsektor, dimana 21 subsektor dibuka dengan tingkat liberalisasi sedang $(\mathrm{IH}=0,5$ untuk tiga subsektor dan $\mathrm{IH}=0,75$ untuk 18 subsektor) dan satu subsektor diberikan tingkat liberalisasi tinggi (IH =1).Pada kerjasama WTO ini, Indonesia membuka sebanyak 23 subsektor dengan tingkat liberalisasi sedang $(\mathrm{IH}=0,5)$. Selanjutnya pada kerjasama AKFTA, Korea menambah jumlah subsektornya menjadi 32 subsektor dengan tingkat liberalisasitinggi pada dua subsektor $(\mathrm{IH}=1)$, tingkat liberalisasi sedang pada 30 subsektor (29 subsektor dengan $\mathrm{IH}=0,75$ dan satu subsektor dengan $\mathrm{IH}=0,5)$, sementara Indonesia hanya menambahkan jumlah satu subsektor menjadi 24 subsektor dengan tingkat liberalisasi sedang. Tingkat liberalisasi setiap subsektor di sektor jasa keuangan disajikan pada Tabel 9. 


\section{Tabel 9. Tingkat LiberalisasiKorea dan IndonesiaPada Kerjasama WTO dan AKFTA di Sektor Jasa Keuangan.}

\begin{tabular}{|c|c|c|c|c|}
\hline \multirow[t]{2}{*}{ Sub sektor } & \multicolumn{2}{|c|}{ Korea } & \multicolumn{2}{|c|}{ Indonesia } \\
\hline & WTO & AKFTA & WTO & AKFTA \\
\hline \multicolumn{5}{|l|}{ - Asuransi Langsung } \\
\hline 1. Jasa asuransi jiwa. & 0,75 & 0,75 & 0,5 & 0,5 \\
\hline 2. Jasa asuransi non-jiwa. & 0,75 & 0,75 & 0,5 & 0,5 \\
\hline 3. Jasa reasuransi dan retrosesi. & 0,75 & 0,75 & 0,5 & 0,5 \\
\hline \multicolumn{5}{|l|}{ - Jasa pialang dan lembaga asuransi } \\
\hline 4. Jasa perantara. & 0,75 & 0,75 & 0,5 & 0,5 \\
\hline 5. Jasa perantara reasuransi. & 0 & 0 & 0,5 & 0,5 \\
\hline 6. Jasa agen. & 0,75 & 1 & 0 & 0 \\
\hline - Layanan tambahan untuk asuransi & 0,5 & 0,75 & 0 & 0 \\
\hline 7. Jasa penyelesaian dan penyesuaian klaim. & 0,5 & 0,75 & 0 & 0 \\
\hline 8. Jasa aktuaria. & 0,5 & 0,75 & 0 & 0 \\
\hline \multicolumn{5}{|l|}{ - Jasa perbankan dan keuangan lainnya } \\
\hline 9. Jasa deposito. & 0,75 & 0,75 & 0,5 & 0 \\
\hline 10. Jasa pinjaman. & 0,75 & 0,75 & 0,5 & 0,5 \\
\hline 11. Jasa pembiayaan keuangan. & 1 & 1 & 0,5 & 0,5 \\
\hline 12. Jasa pembayaran dan penyebaran uang. & 0,75 & 0,75 & 0,5 & 0 \\
\hline 13. Jasa jaminan dan liberalisasi. & 0,75 & 0,75 & 0,5 & 0 \\
\hline 14. Jasa penukaran valuta asing. & 0,75 & 0,75 & 0,5 & 0,5 \\
\hline 15. Jasa kliring. & 0,75 & 0,75 & 0 & 0 \\
\hline
\end{tabular}

- Perdagangan untuk kepentingan sendiri atau untuk kepentingan nasabah, apakah di bursa, di pasar over-the-counter atau sebaliknya

16. Jasa instrumen pasar uang (termasuk cek, tagihan, sertifikat deposito)

17. Jasa pertukaran valuta asing.

18. Jasa produk derivatif keuangan (termasuk berjangka dan opsi).

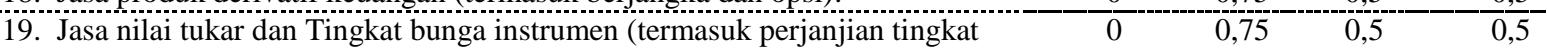
swap dan forward).

20. Jasa sekuritas dipindahtangankan.

21. Jasa surat berharga lainnya dan aset keuangan (termasuk bullion).

\begin{tabular}{|c|c|c|c|}
\hline 0 & 0,75 & 0 & 0,5 \\
\hline 0 & 0,75 & 0,5 & 0,5 \\
\hline 0 & 0,75 & 0,5 & 0,5 \\
\hline 0 & 0,75 & 0,5 & 0,5 \\
\hline 0 & 0,75 & 0,5 & 0,5 \\
\hline 0 & 0,75 & 0,5 & 0,5 \\
\hline
\end{tabular}

- Partisipasi dalam masalah semua jenis surat berharga

\begin{tabular}{l} 
22. Jasa penerbitan sekuritas. \\
23. Jasa penjamin emisi efek. \\
\hline 24. Jasa penempatan.
\end{tabular}

- Manajemen aset: hanya berlaku untuk layanan yang tercantum di bawah ini

26. Jasa manajemen kas dan portopolio.
27. Jasa semua bentuk manajemen investasi kolektif.
28. Jasa custody.

Sumber: data diolah

\section{Sektor Jasa Kesehatan}

Korea belum meliberalisasi sektor jasa kesehatannya, baik pada kerjasama WTO maupun AKFTA, sementara Indonesia juga menutup sektor jasa ini di WTO. Namun demikian, Indonesia telah membuka jasa ini pada kerjasama AKFTA 
namun masih diberikan pembatasan atau dengan tingkat liberalisasi sedang seperti yang ditunjukkan

\section{Tabel 10. Tingkat LiberalisasiKorea}

pada Tabel 10. Hal ini berarti bahwa Indonesia lebih terbuka dari pada Korea di sektor ini. AKFTA di Sektor Jasa Kesehatan.

\begin{tabular}{|c|c|c|c|c|}
\hline \multirow[t]{2}{*}{ Sub-sektor } & \multicolumn{2}{|c|}{ Korea } & \multicolumn{2}{|c|}{ Indonesia } \\
\hline & WTO & AKFTA & WTO & AKFTA \\
\hline $\begin{array}{l}\text { pelayanan rumah sakit (hanya untuk spesialistik dan } \\
\text { super perawatan medis spesialis / lebihspesifik } \\
\text { daripada spesialistik perawatan medis, yang } \\
\text { disediakan oleh rumah sakit lebih dari } 300 \text { tempat } \\
\text { tidur) (CPC 9311). }\end{array}$ & 0,0 & 0,0 & 0,0 & 0,5 \\
\hline
\end{tabular}

Sumber: data diolah

\section{Sektor Jasa Pariwisata}

Korea membuka sebanyak tiga subsektor pada kerjasama WTO dengan tingkat liberalisasi tinggi pada dua subsektor $(\mathrm{IH}=1)$ dan sedang pada satu subsektor (IH 0,75), sementara Indonesia membuka sebanyak dua subsektor dengan tingkat liberalisasi sedang $(\mathrm{IH}=0,5)$. Selanjutnya pada kerjasama AKFTA, Korea menambah dua subsektor yaitu jasa hotel dan restoran dan lansung memberikan tingkat keterbukaan tinggi (dari $\mathrm{IH}=0$ di WTO menjadi $\mathrm{IH}=1$ di AKFTA) serta jasa penyediaan makanan dan minuman dengan tingkat keterbukaan sedang $(\mathrm{IH}=0,5)$. Adapun Indonesia menambah tiga subsektor dengan tingkat liberalisasi rendah pada jasa konsultasi wisata dan jasa operator tur internasional serta tingkat keterbukaan sedang pada jasa resort. Tingkat liberalisasi sektor jasa pariwisata Korea dan Indonesia pada kerjasama WTO dan AKFTA disajikan pada Tabel 11.

Tabel 11. Tingkat Liberalisasi Korea dan IndonesiaPada Kerjasama WTO dan AKFTA di Sektor Jasa Pariwisata.

\begin{tabular}{|c|c|c|c|c|}
\hline \multirow[t]{2}{*}{ Sub-sektor } & \multicolumn{2}{|c|}{ Korea } & \multicolumn{2}{|c|}{ Indonesia } \\
\hline & WTO & AKFTA & WTO & AKFTA \\
\hline $\begin{array}{l}\text { 1. Jasa hotel dan restoran (CPC 641, 642) (Indonesia: } \\
64110,64210 \text { ) }\end{array}$ & 1,0 & 1,0 & 0,5 & 0,5 \\
\hline 2. Jasa hotel dan restoran (CPC $\left.6431^{*}\right)$ & 0,0 & 1,0 & 0,0 & 0,0 \\
\hline 3. Penyediaan minuman dengan hiburan (CPC 6432) & 0,0 & 0,5 & 0,0 & 0,0 \\
\hline 4. Jasa agen perjalanan dan operator tur (CPC 7471) & 1,0 & 1,0 & 0,5 & 0,5 \\
\hline 5. Jasa pemandu wisata $($ CPC 7472$)$ & 0,75 & 1,0 & 0,0 & 0,0 \\
\hline $\begin{array}{l}\text { 6. Jasa Tourist Resort termasuk: } \\
\text { - hotel }(3,4 \text {, dan } 5 \text { bintang) } \\
\text { - marina } \\
\text { - lapangan golf dan fasilitas lainnya olahraga (HCPC } \\
\text { 96.413) }\end{array}$ & 0,0 & 0,0 & 0,0 & 0,5 \\
\hline 7. Jasa konsultasi pariwisata (CPC 91136) & 0,0 & 0,0 & 0,0 & 0,25 \\
\hline 8. Jasa operator tur internasional (CPC 91135) & 0,0 & 0,0 & 0,0 & 0,25 \\
\hline
\end{tabular}

Sumber: data diolah

\section{Sektor Jasa Rekreasi, Hiburan dan Olah Raga}

Indonesia masih menutup sektor ini pada kedua kerjasama ini, sementara Korea juga masih menutupnya pada kerjasama WTO. Korea membuka dan meberikan liberalisasi sedang pada kerjasama 
AKFTA sebagaimana yang satunya subsektor yang dibuka oleh ditunjukkan pada Tabel 9. Satu- Korea tersebut adalah jasa hiburan.

Tabel 12. Tingkat LiberalisasiKorea dan IndonesiaPada Kerjasama WTO dan AKFTA di Sektor Jasa Pariwisata.

\begin{tabular}{|c|c|c|c|c|}
\hline \multirow[t]{2}{*}{ Sub-sektor } & \multicolumn{2}{|c|}{ Korea } & \multicolumn{2}{|c|}{ Indonesia } \\
\hline & WTO & AKFTA & WTO & AKFTA \\
\hline 1. jasa hiburan (CPC 96191, 96192) & 0,0 & 0,5 & 0,0 & 0,0 \\
\hline
\end{tabular}

Sumber: data diolah

\section{Sektor Jasa Transportasi}

Korea telah membuka sebanyak 16 subsektor pada sektor jasa transportasi di WTO dengan tingkat liberalisasi tinggi pada tujuh subsektor, kemudian liberalisasi sedang pada enam subsektor dan tingkat liberalisasi rendah pada dua subsektor. Adapun Indonesia hanya membuka sebanyak satu subsektor dengan tingkat liberalisasi sedang pada kerjasama tersebut. Lebih lanjut pada kerjasama AKFTA, Korea menambah sebanyak lima subsektor dengan tingkat liberalisasi tinggi

Tabel 13. Tingkat LiberalisasiKorea dan IndonesiaPada Kerjasama WTO dan AKFTA di Sektor Jasa Transportasi.

\begin{tabular}{|c|c|c|c|c|}
\hline \multirow[t]{2}{*}{ Sub sektor } & \multicolumn{2}{|c|}{ Korea } & \multicolumn{2}{|c|}{ Indonesia } \\
\hline & WTO & AKFTA & WTO & AKFTA \\
\hline \multicolumn{5}{|l|}{ - Jasa transportasi maritim } \\
\hline $\begin{array}{l}\text { 1. Jasa transportasi internasional (CPC } 7211 *, 7212 *) \text { tidak } \\
\text { termasuk cabotage }\end{array}$ & 0,25 & 0,75 & 0,5 & 0,5 \\
\hline \multicolumn{5}{|l|}{ - Jasa Pelengkap Maritime } \\
\hline 2. Jasa penanganan kargo maritim (CPC $741^{*}$ ) & 1 & 1 & 0 & 0,5 \\
\hline 3. Jasa penyimpanan dan gudang di pelabuhan (CPC $742 *$ ) & 1 & 1 & 0 & 0 \\
\hline 4. Jasa kepabeanan & 1 & 1 & 0 & 0 \\
\hline 5. Jasa agen maritim (CPC $748^{*}$ ) & 0,75 & 0,75 & 0 & 0 \\
\hline 6. Jasa stasiun kontainer (CPC $\left.741^{*}\right)$ & 1 & 1 & 0 & 0 \\
\hline 7. Jasa freight forwarding maritim (CPC 748*) & 0,75 & 0,75 & 0 & 0 \\
\hline 8. Jasa perantara pengiriman (CPC 748*, 749*) & 0,75 & 0,75 & 0 & 0 \\
\hline 9. Jasa pemeliharaan dan perbaikan kapal & 0,75 & 0,75 & 0 & 0 \\
\hline $\begin{array}{l}\text { 10. Jasa sewa kapal dengan awak (CPC 7213) (Indonesia: tanpa } \\
\text { awak) }\end{array}$ & 0 & 1 & 0 & 0,5 \\
\hline 11. Jasa pendorong dan penarik (CPC 7214) & 0 & 1 & 0 & 0 \\
\hline 12. Jasa perhitungan mengukur dan survei (CPC $\left.745^{*}\right)$ & 0 & 1 & 0 & 0 \\
\hline \multicolumn{5}{|l|}{ jasa transportasi udara } \\
\hline 13. Jasa Services Computer reservation system (CRS). & 1 & 1 & 0 & 0,75 \\
\hline 14. Jasa penjualan dan pemasaran transportasi udara. & 1 & 1 & 0 & 0,75 \\
\hline 15. Jasa perbaikan dan pemeliharaan pesawat. & 0 & 1 & 0 & 0,75 \\
\hline
\end{tabular}

pada 14 subsektor. Dengan demikian total subsektor yang dibuka Korea pada kerjasama AKFTA meningkat menjadi 23 subsektor. Adapun Indonesia juga menambah sebanyak lima subsektor. Tiga dari lima subsektor yang ditambahkan Indonesia tersebut diberikan dibuka dengan indeks hoekman yang lebih tinggi yaitu 0,75 . Tingkat liberalisasi pada masing-masing subsektor jasa transportasi kedua negara pada kerjasama tersebut disajikan pada Tabel 13 sebagai berikut.

\section{- Jasa Transportasi Darat}




\begin{tabular}{|c|c|c|c|c|}
\hline \multirow[t]{2}{*}{ Sub sektor } & \multicolumn{2}{|c|}{ Korea } & \multicolumn{2}{|c|}{ Indonesia } \\
\hline & WTO & AKFTA & WTO & $\overline{\text { AKFTA }}$ \\
\hline $\begin{array}{l}\text { 16. Jasa transportasi jalan raya untuk barang tidak termasuk cabotage } \\
\left.\text { (CPC } 71233^{*}\right) \text {. }\end{array}$ & 0,5 & 0,5 & 0 & 0 \\
\hline 17. Jasa taransportasi melalui saluran pipa (CPC $7131 *)$. & 0,5 & 1 & 0 & 0 \\
\hline - Jasa Pelengkap semua Moda Transportasi & & & & \\
\hline $\begin{array}{l}\text { 18. Jasa penyimpanan dan gudang layanan lainnya selain di } \\
\text { pelabuhan (CPC } 742 *)\end{array}$ & 1 & 1 & 0 & 0 \\
\hline 19. Jasa pelengkap transportasi lainnya & 0 & 1 & 0 & $\overline{0}$ \\
\hline jasa kombinasi transportasi & & & & \\
\hline 20. Freight-forwarding untuk transportasi kereta api & 0 & 1 & 0 & $\overline{0}$ \\
\hline
\end{tabular}

Sumber: data diolah

\section{Sektor Jasa Lainnya}

Indonesia membuka sektor jasa lainnya pada kerjsama AKFTA dengan tingkat liberalisasi sedang. Keterbukaan Indonesia ini difokuskan pada jasa energi yang dipadukan dengan jasa bisnis. Subsektor-subsektor yang dibuka
Indonesia umumnya membutuh teknologi tinggi seperti jasa analisis energi nuklir (isotop), jasa survei seismik serta survey bawah permukaan. Adapun Korea masih menutup sektor jasa lainnya. Tingkat keterbukaan Indonesia pada sektor jasa lainnya disajikan pada Tabel 14 .

Tabel 14. Tingkat LiberalisasiKorea dan IndonesiaPada Kerjasama WTO dan AKFTA di Sektor Jasa Lainnya.

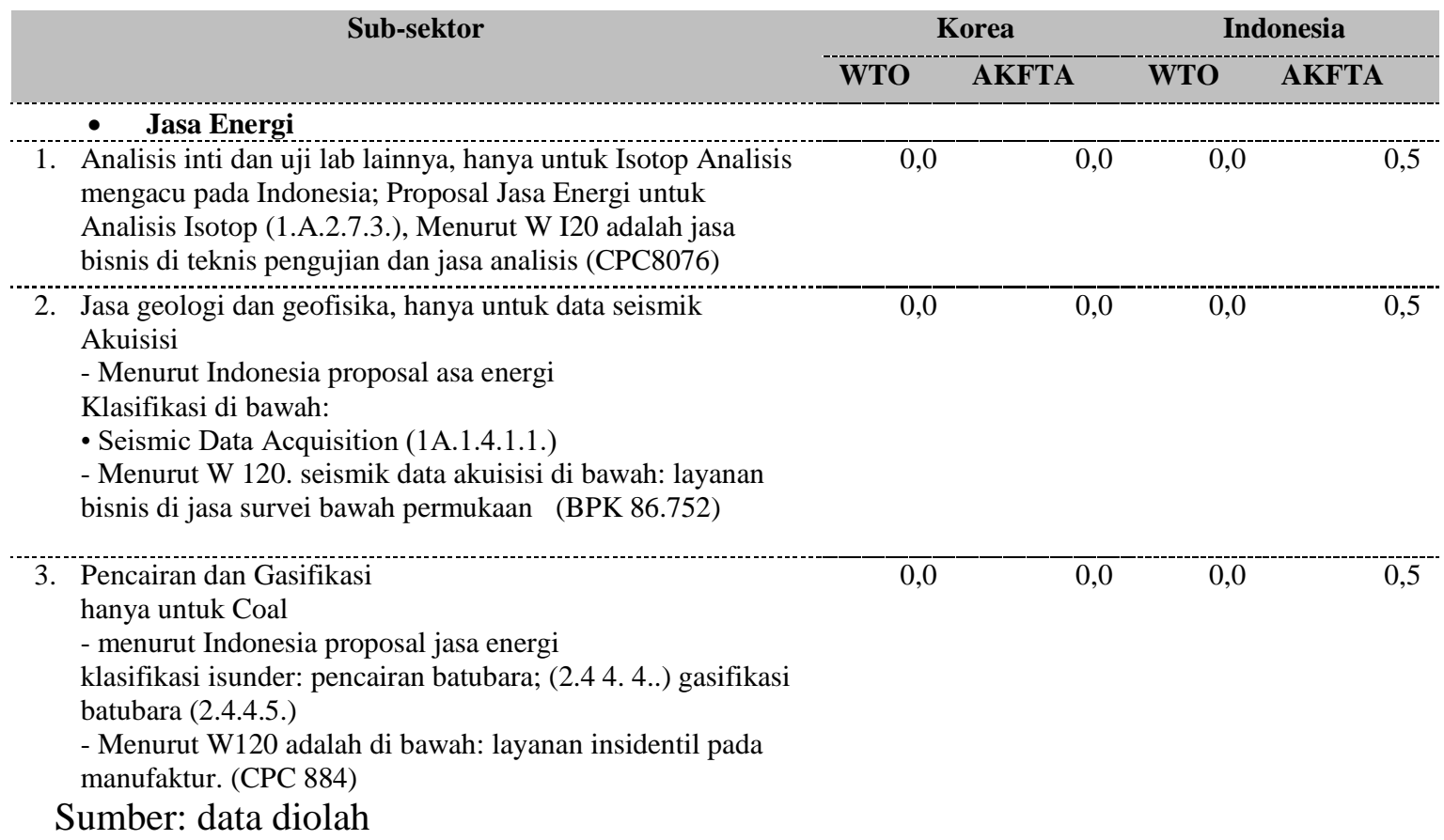

\section{Uji Beda rata-rata pada peningkatan tingkat liberalisasi Korea dari WTO ke AKFTA}

Tingkat liberalisasi Korea meningkat dari rata-rata sedang $(\mathrm{IH}=0,53)$ pada kerjasama WTO menjadi rata-rata dengan kategori tinggi (Indek Hoekman sebesar 0,76) pada kerjasama AKFTA.Perubahan tingkat liberalisasi tersebut terjadi karena komitmen Korea dengan sebanyak 52 
subsektor di WTO dengan tingkat liberalisasi penuh $(\mathrm{IH}=1)$ dan 45 subsektor dengan tingkat liberalisasi 0,75 (skala 1). Lebih lanjut pada kersama AKFTA jumlah subsektor dengan tingkat liberalisasi penuh $(\mathrm{IH}=1)$ meningkat menjadi 88 subsektor dan sebanyak 48 subsektor dengan tingkat liberalisasi sebesar 0,75. Dengan demikian secara umum terjadi peningkatan liberalisasi Korea dalam meliberalisasi sektor jasanya di Moda 3. Namun demikian, untuk mebuktikan siginifikansi dari kenaikan tersebut maka diperlukan pengujian hipotesis dengan uji beda rata-rata seperti yang ditunjukkan pada Tabel 15 sebagai berikut.

Tabel 15. Hasil Uji Beda Rata-rata Tingkat Liberalisasi Korea Pada Kerjasama WTO dan AKFTA

\begin{tabular}{lrr} 
& WTO & AKFTA \\
\hline Mean & 0,53293413 & 0,760479 \\
\hline Variance & 0,189 & 0.110 \\
\hline Observations & 167 & 167 \\
\hline Pearson Correlation & 0,50574521 & 0 \\
\hline Hypothesized Mean Difference & 166 \\
\hline$d f$ & $-7,5057525$ \\
\hline$t$ Stat & $1,7705 \mathrm{E}-12$ \\
\hline$P(T<=t)$ one-tail & 1,65408471 \\
\hline$t$ Critical one-tail & $3,5411 \mathrm{E}-12$ \\
\hline$P(T<=t)$ two-tail & 1,97435776
\end{tabular}

Hasil uji beda rata-rata menunjukkan bahwa nilai t-hitung sebesar -7,506 dan nilai t-tabel sebesar 1,654 atau $-1,654$ (degree of freedomsebesar 166). Oleh karenapengujian hipotesis yang digunakan adalah hipotesis dua arah maka diketahui bahwa hipotesis nol $\left(\mathrm{H}_{0}\right)$ yang menyatakan bahwa tidak terdapat perbedaan yang signifikan antara liberalisasi Korea di WTO dengan di AKFTA ditolak. Hal ini berarti bahwa Korea secara signifikan meningkatkan liberalisasinya dari WTO ke AKFTA. Hal ini juga dapat diartikan bahwa kerjasama AKFTA bermanfat bagi Indonesia karena mendapatkan akses pasar jasa Korea yang lebih besar daripada tingkat liberalisasi yang berlaku MFN di WTO.

Uji Beda rata-rata pada peningkatan liberalisasi Indonesia dari WTO ke AKFTA
Tingkat liberalisasi rata-rata Indonesia pada kerjsama WTO sebesar 0,18 (skala 1) dan meningkat menjadi 0,22 (skala 1) pada kerjasama AKFTA. Tingkat liberalisasi rata-rata Indonesia pada kedua kerjasa tersebut termasuk rendah. Seperti yang telah dijabarkan sebelumnya bahwa tingkat liberalisasi adalah terbuka dengan pembatasan pada semua subsektor jasa yang dibukanya, selain itu, masih banyak subsektor jasa jasa Indonesia yang belum diliberalisasikan. Untuk menguji hipotesis bahwa terjadi peningkatan yang signifikan pada liberalisasi sektor Indonesia dari WTO ke AKFTA maka dilakukan uji beda rata-rata yang ditunjukkan pada Tabel 16 sebagai berikut. 
Tabel 16. Hasil Uji Beda Rata-rata Tingkat Liberalisasi Indonesia Pada Kerjasama WTO dan AKFTA

\begin{tabular}{lrr} 
& \multicolumn{1}{c}{ WTO } & \multicolumn{1}{c}{ AKFTA } \\
\hline Mean & 0,177 & 0,223 \\
\hline Variance & 0,064 & 0,072 \\
\hline Observations & 167,000 & 167,000 \\
\hline Pearson Correlation & 0,761 \\
\hline Hypothesized Mean Difference & 0,000 \\
\hline $\mathrm{d}$ - & 166,000 \\
\hline $\mathrm{t}$ Stat & $-3,309$ \\
\hline $\mathrm{P}(\mathrm{T}<=\mathrm{t})$ one-tail & 0,001 \\
\hline $\mathrm{t}$ Critical one-tail & 1,654 \\
\hline $\mathrm{P}(\mathrm{T}<=\mathrm{t})$ two-tail & 0,001 \\
\hline $\mathrm{t}$ Critical two-tail & 1,974
\end{tabular}

Tabel 16 menunjukkan bahwa nilai t-hitung sebesar -3,309 lebih kecil dari 1,654 yang berarti bahwa menolak hipotesis (H0). Nilai prob. two-tail sebesar 0,001 yang lebih keci dari 0,05 juga menunjukkan bahwa pada taraf $5 \%$ menolak $\mathrm{H}_{0}$. Hal ini berarti bahwa liberalisasi sektor jasa Indonesia di AKFTA telah signifikan peningkatannya dibandingkan dengan tingkat liberalisasinya di WTO.

\section{KESIMPULAN DAN REKOMENDASI KEBIJAKAN}

Korea membuka akses pasar jasa di Moda 3 dengan liberalisasi tinggi sejak Putaran Uruguay (WTO). Sebanyak 52 dari 104 subsektor diliberalisasisecara penuh tanpa pembatasan oleh Korea dengan indeks hoekman satu. Sebaliknya Indonesia belum meberikan tingkat liberalisasi penuh pada subsektor jasanya di WTO.Tingkat liberalisasi tinggi 0,75 (skala 1)diberikan Indonesia hanya pada enam dari 56 subsektor, sedangkan 50 subsektor lainnya diberikan tingkat liberalisasisebesar $\quad 0,5$. Liberalisasi perdagangan jasa Korea dan Indonesiadilanjutkan pada kerjasama AKFTA. Pada kerjasama ini Korea menambah jumlah subsektor jasanya menjadi 147 dengan liberalsiasi penuh pada 88 subsektor. Adapun Indonesia juga menambah jumlah subsektornya menjadi 72 subsektor.

Secara rata-rata statistik, tingkat liberalisasi Korea meningkat dari 0,53 menjadi 0,76. Tingkat liberalisasi Indonesia juga mengalami peningkatan dari 0,18 menjadi 0,22. Peningkatan liberalisasi kedua negara tesebut kemudian di uji menggunakan uji beda rata-rata (uji t-statistik) dengan $\mathrm{H}_{0}$ yaitu tidak terdapat perbedaan yang signifikan antara liberalisasi WTO dengan di AKFTA. Hasil pengujian tersebut menunjukkan bahwa terjadi peningkatan tingkat liberalisasi kedua negara secara signifikan dari WTO ke AKFTA atau dengan kata lain menolak $\mathrm{H}_{0}$. Hal ini juga berarti bahwa RTA bermanfaat pada peningkatan akses pasar jasa kedua negara.

Korea sudah jauh lebih liberal dibandingkan Indonesia terutama pada kerjasama AKFTA. Dengan demikian, pada kerjasama lanjutan dalam hal iniIndonesia-Korea Comprehensive Economic Agreement (IK-CEPA), Indonesia akan lebih tuntut untuk meningkatkan leberalisasi sektor jasanya. Hal ini disebabkan karena masih banyak sektor-sektor jasa yang belum dibuka oleh Indonesia serta masih sangat rendahnya tingkat liberalisasi Indonesia. Peningkatan 
liberalisasi sektor jasa Indonesia ke depan bukan hanya menjadi tuntutan liberalisasi tetapi juga membawa manfaat bagi peningkatan kinerjasa sektor jasa Indonesia. Hal ini sesuai dengan temuan Findly dan Pangestu (2016) bahwa tingginya restriktifitas Indonesia pada sektor jasa berpengaruh pada buruk kinerja sektor jasa Indonesia. Aldaba dan Aldaba (2012) juga mengemukakan bahwa restriksi regulasi dapat menurunkan efisiensi dan persaingan sektor jasa. Untuk itu, ke depan liberalisasi jasa Indonesia di Moda 3 dapat ditingkatkan sesuai dengan Peraturan Presiden Nomor 44 Tahun 2016 Tentang Bidang Usaha Tertutup dan Bidang Usaha yang Terbuka dengan Persyaratan di Bidang Penanaman Modal.

\section{DAFTAR PUSTAKA}

Aldaba, R.M. dan F. Aldaba. (2012). Services Liberalization in the Philippines: A Capacity Needs Assessment for AEC 2015. Philippine Journal of Development, Vol. 39 (1), 23-45.

DeutscheWelle. (2014). Diunduh tanggal 1 Juni 2016 dari http://www.dw.com/en/standstillat-the-world-trade-organization/a17566590.

Fawaiq, M. (2014). Peluang Ekspor Jasa Indonesia ke Jepang Melalui Mode 3 (Commercial Presence) dan Moda 4 (Movement of Natural Persons) Pada Kerjasama IJEPA. Buletin Ilmiah Litbang Perdagangan, Vol. 8, (1), 25-50.

Fawaiq, M. (2015). Analisis Moda Entri Penyedia Jasa Ritel Indonesia Ke ASEAN: Studi Kasus Pada Alfamart. Buletin Ilmiah Litbang Perdagangan, Vol. 9, (1), 25-43.

Findly dan Pangestu. (2016).The Services Sector as a Driver of Change:
Indonesia's Experience in The ASEAN Context. Buletin of Indonesian Economic Studies, Vol. 52 (1), 27-53.

Hicks, R. dan S. Y. Kim. (2012). Reciprocal Trade Agreements in Asia: Credible Commitment to Trade Liberalization or Paper Tigers?.Journal of East Asian Studies, Vol. 12 (1), 1-29.

Hoekman, B. (1995). Assessing the General Agreement on Trade in Services. World Bank Discussion Paper No. 307, World Bank, Washington D.C.

Iyiomo, O.A. dan O.M Sanjo. (2012). Impact of General Agreement on Trade in Services on Education in Nigeria. International Journal of Humanities and Social Science, Vol. 2 (16), 171-179.

Ishido, H. (2012). "Liberalization of Trade in Services under ASEAN+n FTA: A Mapping Exercise". Journal of East Asian Economic Integration, Vol. 16 (2), 155-204.

Latrille dan Lee. (2012). Services Rules in Regional Trade Agreements : How Diverse and How Creative as Compared to The GATS Multilateral Rules?. Geneva: WTO.

Peraturan Presiden Republik Indonesia Nomor 44 Tahun 2016 Tentang Daftar Bidang Usaha Tertutup dan Bidang Usaha Terbuka dengan Persyaratan di Bidang Penanaman Modal. 2016. Jakarta.

Sood, Muhammad. Hukum Perdagangan Internasional, Jakarta: PT Raja Grafindo Persada,

2012.

Tongson dan Cheong. (2016). The ASEAN Trade in Services (AKTIS) Agreement: Its Impact on 
Jurnal Ilmiah Econosains

Vol. 15 No. 2 Agustus 2017

Indonesia and Other ASEAN Countries. Buletin of Indonesian Economic Studies, Vol. 52 (1), 101-117.

World Trade Organization (WTO). (2001).Guidelines For The Scheduling of Specific Commitments Under The General Agreement On Trade In Services (Document S/L/92). (Geneva: WTO Secretariat), 3-13.
E-ISSN: 2252-8490

http://doi.org/10.21009/econosains.015.2.1 